\title{
Piotra Cieplaka gry z teatralnością
}

\author{
DOI: http://dx.doi.org/10.12775/LC.2018.015
}

\begin{abstract}
Streszczenie: Teatr Piotra Cieplaka rodzi się z upodobania do paradoksów i swobodnego poruszania się po odmiennych estetykach i domenach teatru. Cieplak jest zarówno autorem teatralnych inscenizacji inspirowanych historiami biblijnymi, jak i fars, spektakli dla dzieci oraz przedstawień rezonujących spoleczno-polityczną sytuacją dzisiejszej Polski. Prezentowana w artykule droga reżysera z pokolenia tzw. młodszych zdolniejszych, debiutujących w Polsce po 1989 roku, służy analizie elementów determinujących jego język sceniczny, którego immanentną cechą są gry z teatralnością, a ta wywodzi się z różnych żywiołów: idei teatru misteryjno-moralitetowego, teatru ludycznego, teatru offowego, metateatralności, upodobania do paradoksów i absurdu, krytyki mitologizacji Polski i performatywnie kreowanej audiosfery przedstawień.
\end{abstract}

Słowa kluczowe: Piotr Cieplak, teatr polski po 1989 roku, misterium, Biblia, muzyczność

\section{Piotr Cieplak’s games with theatricality}

\begin{abstract}
The main feature of Piotr Cieplak's theatre is predilection for paradoxes and free movement on different aesthetics and theatre domains. Cieplak is both the author of theatrical productions inspired by Bible, as well as farces, performances for children and performances resonating with the social and political situation of today's Poland. The theatre work of the director from generation debuting after 1989 - so-called "younger talented" is analyzed by the determination to the games with theatricality derived from: the idea of the mistery and morality play, ludic theatre, off theatre, metatheatre, paradox and absurd, criticism of the mythologization of the Polish indentity, and performatively created audiosphere of performances.
\end{abstract}

Keywords: Piotr Cieplak, Polish Theatre after 1989, mystery play, Bible, musicality

\footnotetext{
Adiunkt w Katedrze Kulturoznawstwa Uniwersytetu Mikołaja Kopernika w Toruniu. Główne zainteresowania badawcze: teatr i dramat polski XX wieku, historia i teoria teatru lalkowego, teatr dla dzieci i młodzieży, zarządzanie kulturą, pedagogika teatru, animacja kultury. E-mail: marzennaw@umk.pl.
} 
est rok 1989, czas przełomu politycznego, społecznego i kulturalnego w Europie Wschodniej, w którym nie do końca jeszcze jasne są procesy, jakim będzie podlegać Polska odzyskująca niezależność i demokrację. Szkoły teatralne opuszcza pokolenie reżyserów mających świadomość, że nowa sytuacja kraju daje im szansę tworzenia teatru uwolnionego od powinności polityczno-historycznych oraz paradygmatu romantycznego i szukania własnego teatralnego pisma. Są w tym gronie m.in. Anna Augustynowicz, Zbigniew Brzoza, Grzegorz Jarzyna, Krzysztof Warlikowski i Piotr Cieplak. Po 1989 roku przylgnie do nich budzące spory określenie „młodsi zdolniejsi” Piotra Gruszczyńskiego, które, jak podkreślał jego autor, nie ustanawiało pokoleniowej jednorodności, podkreślało natomiast wyczulenie tej grupy reżyserów na nową polską rzeczywistość, znaczoną szybkim przyswajaniem zachodnich modeli ekonomiczno-społecznych i kulturowych, otwarciem na kulturę popularną i rewizją świata wartości (Gruszczyński 2003: 17-27).

Spośród tych reżyserów Piotr Cieplak jest tym, który zaczął raczej nieśmiało i mało nowocześnie, jak określiła to Maria Prussak, bo od lekkich jednoaktówek i farsy (Prussak 2007: 27-36). Swoje pierwsze reżyserskie kroki stawiał na scenie Teatru im. Wilama Horzycy w Toruniu, gdzie Krystyna Meissner dała mu pole do realizacji spektaklu dyplomowego, jednoaktówek Aleksandra Fredry Jestem zabójca i Pierwsza lepsza (1989). Zatrudniony w toruńskim teatrze na stanowisku reżysera (1990-1991), trafil na dobry czas tej sceny. Meissner wyreżyserowała wtedy Pchtę Eugeniusza Zamiatina (1989), zrealizowaną językiem teatralnej alternatywy w dawnym forcie pruskim, za którą zdobyła najważniejsze nagrody XXXI Festiwalu Teatrów Polski Północnej, oraz Wieczór polski według Nie-Boskiej komedii Zygmunta Krasińskiego i Małej apokalipsy Tadeusza Konwickiego (1990). W tym okresie dyrektorka toruńskiej sceny podjęła odważną decyzję - w miejsce FTPP powstał Międzynarodowy Festiwal Teatralny „Kontakt” (1991), który miał umożliwić teatralny dia$\log$ Wschodu z Zachodem. Z Torunia Cieplak wyjechał do Theatre International Exchange w Filadelfii w ramach wspólpracy miast partnerskich. Podsumowaniem jego teatralnej rezydencji był kabaretowy spektakl na podstawie Kubusia Puchatka według Alana Aleksandra Milne’a (1991) na scenie TIE, portretujący amerykańską rzeczywistość widzianą oczami młodego, polskiego artysty (do tego tematu reżyser powrócił w 1999 roku w warszawskim Teatrze Studio). W rewanżu Teatr im. Wilama Horzycy przyjął u siebie młodą reżyserkę, Tammarah Carper, która przygotowała z toruńskimi aktorami Problem (1991)1 ${ }^{1}$, próbę otwartą według jednoaktówki Alberta Ramsdella Gurneya Jra (Jagła 1991).

Toruńskie początki Cieplaka przyniosły poza debiutem jeszcze dwie realizacje. Pierwszym ważnym sukcesem w jego karierze była inscenizacja farsy Żołnierz królowej Madagaskaru Stanisława Dobrzańskiego w opracowaniu Juliana Tuwima (1990), za którą otrzymał nagrodę dla młodego reżysera na Festiwalu Klasyki Polskiej w Opolu w 1991 roku. Spektakl o aurze teatrów ogródkowych, jak pisała Justyna Kozłowska (Kozłowska 2008a: 244), zdradzał ważną cechę dla całej jego późniejszej twórczości - upodobanie do tropienia teatralności teatru, do uprawiania metateatralnej gry, w której igrają ze sobą różne konwencje i formy scenicznej ekspresji oraz obecności, a w kreacji, sztuczności teatralnego świata powstają pęknięcia, szczeliny dla doświadczeń upominających się o egzystencjalny

\footnotetext{
1 W przedstawieniu zagrali Jolanta Teska i Michał M. Ubysz.
} 


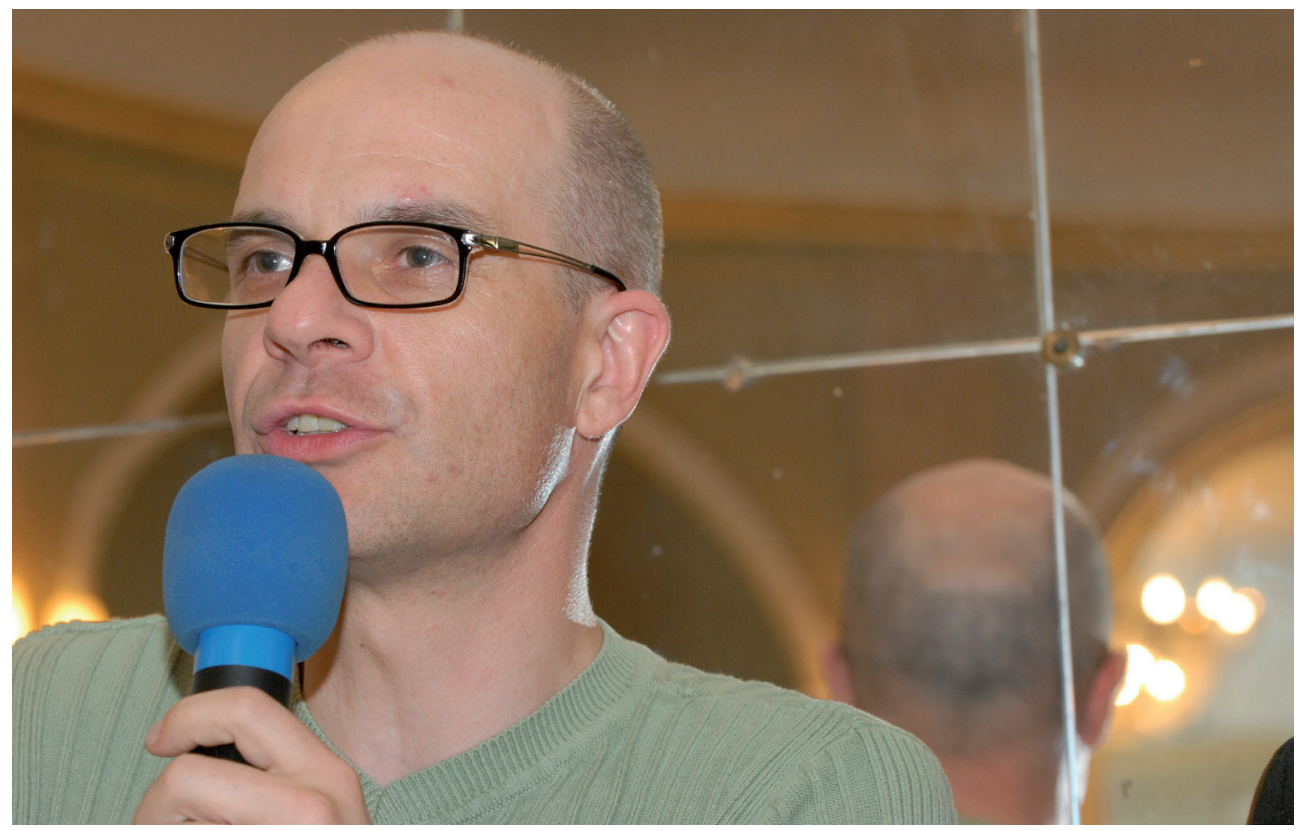

\section{Piotr Cieplak}

Fot. Wojtek Szabelski. $\mathrm{Z}$ archiwum Teatru im. W. Horzycy namysł nad ludzkim losem. Kolejny toruński wybór repertuarowy, czyli Tragik mimo woli Antoniego Czechowa (1991), w kontekście eksplozji postmodernistycznych strategii dramaturgicznych, wyostrzonych, bolesnych analiz tożsamościowych w teatrze i coraz silniej oddziałującej estetyki filmowej, utrwalał poczucie, że Cieplak specjalizuje się w sprawnej realizacji dobrze skrojonych przedstawień i jest daleki od buntowniczego i niepokornego gestu pokolenia „młodszych zdolniejszych”. Wkrótce okazało się jednak, że ta odrębność wśród debiutujących z nim reżyserów czekała tylko na właściwy moment pełnego rozkwitu. I już w 1993 roku wydała owoc w postaci autorskiego, osobnego teatru, który zaczął się od Historyi o Chwalebnym Zmartwychwstaniu Pańskim Mikołaja z Wilkowiecka.

Toruń był pierwszym miejscem, gdzie Cieplak chciał zrealizować pomysł inscenizacji misterium średniowiecznego ${ }^{2}$. Tekst ten pojawił się w polu jego zainteresowań, o czym pisała Sylwia Jarmuż, po niespełnionej ostatecznie przymiarce do realizacji kabaretu inspirowanego staropolskimi tekstami, m.in. Krótka rozprawa między trzema osobami, Panem, Wójtem a Plebanem i Albertusami, a wymierzonego przeciwko narodowo-religijnemu programowi Zjednoczenia Chrześcijańsko-Narodowego (Jarmuż 2013: 101). W trakcie pracy nad montażem kabaretu Cieplak przeniósł uwagę na ekspresję religijnych i ludzkich uczuć w takich utworach, jak np. Żale Matki Boskiej pod Krzyżem i podjął próbę dramaturgiczno-teatralnego przepracowania staropolskiej spuścizny, co doprowadziło go ostatecznie do misterium Mikołaja z Wilkowiecka. W tym zwrocie ku literaturze średniowiecznej był Cieplak rzeczywiście odosobniony na tle swojego pokolenia, a ryzyko tego wyboru teatralnego wzmacniał dodatkowo fakt, że wkraczał na teren wielkiej polskiej tradycji in-

2 Taką informację podawała Anna Błaszczak, kierowniczka literacka Teatru im. Wilama Horzycy (1983-1996). Zob. też Jarmuż 2013: 101. 
scenizacji staropolskich, znaczonych nazwiskami Leona Schillera i Kazimierza Dejmka. W świat dawnych tekstów wkroczył bardzo samodzielnie i odważnie, wyposażony w impulsy twórcze z różnych porządków, m.in. z reżyserskiej gry z teatralnością komedii i fars, z przyswajanego na poboczach własnej pracy języka teatralnego offu (jeszcze w czasach studenckich i na początku drogi twórczej brał udział w warsztatach Teatru Ósmego Dnia i warsztatach reżyserskich z Peterem Brookiem ${ }^{3}$ ), z estetyki undergroundowych grup rockowych, z krytycznego zapału w ocenie społeczno-politycznej sytuacji Polski połowy lat 90., wreszcie z potrzeby stawiania w teatrze egzystencjalnych pytań o człowieka u progu XXI wieku, które rozpinały się między zapoznawanymi jeszcze na studiach refleksjami z Filozofi dialogu Józefa Tischnera a dramatami Samuela Becketta (Kozłowska 2008a: 240261; Kozłowska 2008b). Premiera Historyi o Chwalebnym Zmartwychwstaniu Pańskim odbyła się na scenie Teatru Współczesnego we Wrocławiu w 1993 roku i z sukcesem wpisała staropolskie misterium w środki nowocześnie uprawianego teatru. Wrocławska Historyja... zdobyła Grand Prix XIX Konfrontacji Teatralnych Klasyki Polskiej w Opolu, a warszawska wersja (Teatr Dramatyczny, 1994) otrzymała Nagrodę Akredytowanych Dziennikarzy na Międzynarodowym Festiwalu Teatralnym „Kontakt” 1996. Dwa lata później prezentowana na toruńskim festiwalu Historia o Miłosiernej, czyli Testament psa Ariano Suassuny (Teatr Rozmaitości w Warszawie) potwierdzała specjalizację Cieplaka w wykorzystywaniu środków teatru alternatywnego i żywiołu muzyki na żywo do naruszania struktur inscenizacyjnych w teatrze dramatycznym (spektakl zdobył Nagrodą Dziennika „Gazeta Pomorska - Media” za urodę plastyczną przedstawienia). Co ciekawe, gdy Cieplak przyjechał na „Kontakt” po raz trzeci, do pejzażu europejskiego teatru początku XXI wieku dokładał spektakl, który zdawał się powrotem do początków teatralnej kariery. Pokazując w 2006 roku Stomkowy kapelusz Eugène Labiche’a (Teatr Powszechny), reżyser był jednak już w innym miejscu swojej drogi twórczej. Przedstawienie według konwencji farsy było równocześnie przeciw niej, pisała Kozłowska (Kozłowska 2008a: 244), w duchu „wodewilowego Koheleta" (Kozłowska 2005: 148-153) toczyła się w nim gra bohaterów o życie $\mathrm{w}$ teatrze świata, a precyzyjną strukturę sztuki dobrze zrobionej rozsadzała obnażana ze sceny na scenę teatralność rzeczywistości przedstawionej.

Nakreślony tu toruński początek Cieplaka w kontekście jego późniejszej obecności na festiwalu „Kontakt” wydobywa rzecz znamienną: choć sam reżyser dystansował się od swoich pierwszych realizacji, mówiąc, że poprzedzały one moment, w którym naprawdę zorientował się, jaki teatr jest mu bliski (Cieplak 1998), to w tej drodze od farsy do misterium i z powrotem można dostrzec zapowiedź paradoksów, które regularnie będzie on eksplorował w teatrze. Wyobraźnia teatralna Cieplaka żywi się konfrontacjami konwencji i estetyk, napięciami między tym, co niskie, i tym, co podniosłe, przenikaniem się śmiechu, żartu, absurdu z pytaniami ostatecznymi i powagą słów podstawowych, przezieraniem metafizyki przez codzienność i łączeniem tajemnic religijnych z ludzką zwyczajnością, współistnieniem obok siebie języka wielkich opowieści i rytmu mowy potocznej, grą teatralności z doświadczeniem sytuacji spotkania „tu i teraz”. U Cieplaka farsa nabiera metafizycznego tonu, a tajemnicę misteryjnych spraw bosko-ludzkich rozsadza żywioł rubaszno-ludyczny. $\mathrm{Z}$ upodobania do paradoksów wynika swoisty eklektyzm reżyserskiej twórczości Cieplaka,

\footnotetext{
3 Warsztaty w Wiedniu w 1992 roku. Cieplak wielokrotnie przywołuje w swoich wypowiedziach myśli P. Brooka, nazywając go nawet swoim papieżem teatru. Zob. Cieplak 2002: 46.
} 
na co zwracał uwagę Tadeusz Kornaś (Kornaś 2010: 254). Jest chyba obecnie jedynym polskim reżyserem teatralnym, który wchodzi w tak rozmaite konstelacje artystyczne i pracuje w, zdawałoby się, „krańcowo odmiennych estetykach” i domenach teatru (Kornaś 2010; Prussak 2007: 32-33). Cieplak umie poruszać się artystycznie w rozmaitych światach: obok jego rozpoznawalnych historii biblijnych Starego i Nowego Testamentu sytuują się William Shakespeare, Aleksander Fredro, Adam Mickiewicz, Stanisław Wyspiański, Thomas S. Eliot, Samuel Beckett, Eugène Labiche, Isaak B. Singer, Miron Białoszewski, współcześni autorzy polscy - Jerzy Pilch, Artur Pałyga, Marcin Świetlicki oraz twórcy XX-wiecznej literatury dla dzieci i młodzieży - Alan A. Milne, Julian Tuwim, Tankred Dorst, Janosch.

Niepokorny ruch twórczy Cieplaka przynosi pulsujące struktury przedstawień, otwarte na środki wyrazowe teatru alternatywnego w zakresie ekspresji aktorskiej, naruszające ramy i podziały przestrzeni scenicznej (np. pierwsza część Albośmy to jacy tacy..., Teatr Powszechny im. Zygmunta Hübnera, 2007), często na rzecz tworzenia ascetycznej, pustej przestrzeni, gdzie w centrum znajdują się człowiek-aktor i człowiek-widz oraz słowo. Równocześnie alternatywna formacja Cieplaka skłania go do regularnego przekraczania teatru repertuarowego jako instytucji. Tworzy przedsięwzięcia zakorzenione w teatrze formy z Teatrem Montownia, projekty taneczne z Dada von Bzdülöw i Leszkiem Bzdylem, performanse słowno-muzyczne rozpisane na improwizacje SzaZy ( O niewiedzy w praktyce, czyli rowerem do Portugalii, 2010), performatywne wydarzenia teatralne (m.in. Historia o narodzeniu Pana Jezusa na Dworcu Centralnym, 2003), prowadzi warsztaty. Cieplak podkreśla, że jest w tym wychodzeniu $\mathrm{z}$ teatru i wchodzeniu do teatru rodzaj gry z teatralnością jako fenomenem, który zdarza się w napięciu między sztucznością a prawdziwością - to jego sposób badania wytrzymałości szwów teatru (Prussak 2003).

Swoboda poruszania się Cieplaka między teatralnymi środowiskami miała wpływ nie tylko na jego osobiste wybory reżyserskie, ale stanęła u podstaw manifestu, gdy obejmował kierownictwo artystyczne Teatru Rozmaitości w Warszawie (1996-1998). Cieplak zasłynął z haseł: „najszybszy teatr w mieście”, „martensy w teatrze”, „czadowy teatr”, „teatr w glanach", które poza niewątpliwą chwytliwością marketingową oddawały ducha zmiany profilu warszawskich Rozmaitości na miejsce „pulsujące w rytmie naszych czasów” (Janikowski 1998: 120), przeznaczone dla publiczności wychowanej na ostrym brzmieniu rockowym, wizualności kultury popularnej, filmach Quentina Tarantino i Davida Lyncha. Poza wprowadzeniem nowego stylu rozmowy z widownią, szczególnie młodą, którą teatr zaczął przyciągać jak magnes, Cieplak z nie mniejszą energią, z „harcerskim entuzjazmem” (Cieplak 1997), jak sam mówil, chciał rozmontowywać tradycyjny model pracy w teatrze. Marzył mu się teatr z ducha offowy, w którym będzie odbywała się organiczna praca zespołu aktorskiego nad poszerzaniem możliwości wyrazowych i rozwijaniem przedsięwzięć spoza nurtu dramatycznego - temu służyły tzw. Off-maitości.

$\mathrm{Na}$ zasadzie paradoksu ów awangardowy rytm teatru Cieplak lubił sprzęgać z tekstami literatury dawnej, dając im nierzadko gorące, współczesne wcielenia sceniczne. Utworem nieustannie obecnym w jego teatralnych przedsięwzięciach jest Biblia. 


\section{Teatr wywiedziony z Księgi}

Reżyser jest jak organizator meczu, „napina potencjały dobra i zła, niech się mocują, niech się kłębią", zagrzewa do walki i patrzy, jak toczy się gra (Cieplak 2002) - piłkarskie porównania regularnie powracają w wypowiedziach Cieplaka. Równie namiętnie śledzi rozgrywki ligowe, co czyta Biblię. Sport i teologia, w myśl jego ulubionej zasady paradoksu, wzajemnie się oświetlają. Psalmy w przekładzie Miłosza znalazły się w jego skromnym rowerowym ekwipunku podczas wyprawy do Portugalii i oplatały spostrzegane obrazy oraz zwyczajny ból otarć i zmęczonych mięśni rytmem lirycznego namysłu nad człowiekiem w tajemnicy boskiego planu stworzenia (Cieplak 2014). Cieplak jest obecnie jedynym reżyserem, który konsekwentnie, acz bez konfesyjności, sięga w teatrze po słowo szczególne - tekst Biblii (Księga Hioba, Teatr Współczesny we Wrocławiu, 2004; Milczenie o Hiobie, Teatr Narodowy, 2013) i z uporem wnikliwego czytelnika pyta, tropi niepokoje, zmaga się z zapisanymi w nim myślami i ludzkimi doświadczeniami. W Biblii interesują go konflikt, bieguny napięć między dobrem i złem, dynamiczne zmagania człowieka, w których objawiają się jego ułomności, namiętności, zdziwienia oraz duchowe niepokoje, szuka niedopowiedzeń w jej „odświętnej mowie” (Janowska 2007: 60). Zarazem krytycznie komentuje polski zwyczaj zawłaszczania Słowa Księgi przez religijno-narodowe ruchy i wprzęgania go w jarzmo politycznego interesu.

Do Cieplaka przylgnęły określenia „teatralnego ewangelisty”, „moralisty”, „katechety”, „świętego buntownika”. Gruszczyński pisał o nim:

Cieplak jest wielkim moralistą nowych czasów, i to moralistą wyjątkowo skutecznym, bo umie mówić żywo, językiem pełnym emocji. Moralizatorstwo wyszło dawno z mody, stąd teatralna forma, która czyni to kaznodziejstwo przebiegle atrakcyjnym (Gruszczyński 1997).

Paweł Goźliński na łamach „Notatnika Teatralnego” porównywał Cieplaka z Hugo Hofmannstahlem i Paulem Claudelem z racji jego pasji do rekonstruowania „więzi z odrzuconą pochopnie tradycją średniowiecznego świata widowisk” (Goźliński 1998: 65-77). Gdy końcówka wieku XX przynosiła Polakom pierwsze rozczarowania wczesną demokracją i kazała mierzyć się z ponowoczesnym światem, kryzysem wielkich narracji, relatywizmem, Cieplak zwrócił się ku tradycji misterium teatralnego i moralitetu oraz ku dramaturgii ludzkich spotkań z tajemnicą Boga i w kilku realizacjach stworzył autorski teatr zadający tekstom religijnym pytania nieortodoksyjne, po ludzku obarczone wątpliwościami, niepewnością, pamięcią bólu i zła, ale zarazem teatr otwarty na to, że istnieje coś poza ludzką miarą świata.

Misteryjno-moralitetowy teatr Cieplaka zaczął się od Historyi o chwalebnym Zmartwychwstaniu Pańskim, która powstała trzydzieści dwa lata po słynnej inscenizacji Kazimierza Dejmka (Teatr Nowy w Łodzi, 1961). Cieplak zrobił to misterium po swojemu, dystansując się wręcz od tradycji jego wystawień. Jego Historyja... powstała pod znakiem Jesus Christ Superstar, jak słusznie zauważał Janusz Majcherek (Majcherek 1993), co przejawiało się w na wskroś nowoczesnym języku sceny. Z Beatą Wodecką zaprojektował wielopoziomową przestrzeń, coś na kształt spichlerza z piętrzącymi się workami ziaren, hali po wygasłej fabryce, widzów umieszczając we wnętrzu scenicznych zdarzeń. Współczesny 
kostium ewangelicznych bohaterów, rekwizytorium sceniczne spokrewnione z estetyką teatru alternatywnego, audiosfera tworzona na żywo przez rockowy zespół Kormorany, która wypełniała przestrzeń mocnym brzmieniem, ostrym riffem i przenikliwymi, ezoterycznymi wokalizami, a wreszcie partytury działań aktorów rozpięte między skupieniem a gwałtownością, prostotą codziennych gestów i symbolicznych znaków, rozpisane na precyzyjnie prowadzone napięcia i pauzy, kompozycje ruchowe i zmienne rytmy - wszystko to tchnęło estetyczną nowością w polskim teatrze dramatycznym. Zachowane brzmienie staropolskiego języka postaci nadawało całości wymiaru poetyckiego, wzmacnianego dodanymi przez Cieplaka intermediami, wśród których najmocniej zapadał w pamięci sen o dębie. Myśleniu o staropolskim misterium patronował od samego początku Miron Białoszewski. Wrocławski program zamykały jego słowa starej pieśni na Binnarową: „W nawie / na cieniach zastrzałów / ostatnia tajemnica: / po lewej ręce / zbawieni, / po prawej / potępieni, / / a wszyscy / przyprószeni... / Amen” (Teatr Współczesny im. Edmunda Wiercińskiego we Wrocławiu, sezon 1993/1994). Wspomniany już Majcherek pisał w recenzji:

Cieplak potraktował język Mikołaja z Wilkowiecka tak, jakby to był język Białoszewskiego jest piękny i paradoksalnie komunikatywny przez to właśnie, że taki koślawy i niezgodny z normą. Pokrewieństwo widzę także w formie - ta Historyja ma coś wspólnego z Teatrem Osobnym, zwłaszcza może z tekstami typu Wyprawy krzyżowe czy Osmędusze: pomieszanie „niskiego” z „wysokim”, folkloru z tradycją „uczoną”, współczesności z historią. I to robienie teatru z byle czego, z przedmiotów i rekwizytów - jak powiedziałby Bruno Schulz - najniższej rangi. I to napięcie między „metafizycznym” a „pospolitym” czy zgoła „trywialnym”, między liryzmem a komizmem. To jest akt wiary żywy przez to, że niejako uzasadniony na wszystkich piętrach rzeczywistości, której naiwność i pospolitość właściwie w każdym momencie spotyka się z Tajemnicą i nie zawsze umie ją rozpoznać. Akt wiary i miłości, który nie potrzebuje spekulacji, jurysdykcji, instytucjonalnie przestrzeganego rytuału - piękne przedstawienie wymierzone w gruncie rzeczy we wszelkiej maści doktrynerów i faryzeuszy, przedstawienie, które bez demonstracji i totalizmu oficjalnych strażników wiary pokazuje, czym naprawdę są wartości chrześcijańskie i gdzie naprawdę mieszka Bóg (Majcherek 1993).

Cieplak wydobył performatywność rezurekcyjnej opowieści ani nie czyniąc z teatru świątyni, ani nie ograniczając teatralności do ludycznych konwencji. Stworzył autonomiczną przestrzeń, która eksponowała zarówno teatralny cudzysłów, choćby poprzez koncept diabłów/aniołów, jak i wzmacniała doświadczenie namacalności, realności wydarzeń sprzed dwóch tysięcy lat. Bohaterami zdarzenia byli przeciętni, zwyczajni ludzie, bo tak Cieplak zobaczył zarówno gromadę uczniów Jezusa topiących pytania po śmierci Chrystusa w kuflach piwa, Maryje skrzętnie zakupujące olejki, jak i antenatów rodu ludzkiego przeciskających się przez rurę, którą równie zwyczajny Jezus (Piotr Kondrat) czynił wyłom we wrotach piekła. Cudowność teatralnej machiny i zwyczajność połączył Cieplak w zwarty splot, z którego utkał materię teatru metafizycznego z ducha Tischnerowskiej filozofii świata jako sceny dramatu i człowieka jako istoty dramatycznej (Tischner 1998). Wychodząc z założenia, że teatr i kościół to dwa odmienne porządki, Cieplak równocześnie sytuował scenę po stronie tych miejsc, w których trzeba „powtarzać stare słowa, takie jak miłość, zdrada, Pan Bóg, grzech, te wszystkie przedziwne słowa, które wierzę, że istnieją, tylko mamy kłopoty $\mathrm{z}$ ich rozpoznaniem. Cały sens tej roboty to je wydobyć" (Pawłowski 1997).

Człowiek widziany na tle misteryjnego teatru trzech planów: nieba, ziemi i piekła zagościł w teatrze Cieplaka na dłużej. W Historii o Miłosiernej, czyli Testamencie psa reżyser 
sytuował go nadal w rzeczywistości, która precyzyjnie i zgrabnie balansowała między buffo, farsą i ludycznym wyobrażeniem zaświatów a powagą eschatologicznego kontekstu śmierci (Kornaś 2010). Z przerażającą lekkością objawiały się tu ludzka głupota, naiwność, skrzywione sumienia, grzech i pozór religijnych gestów, a teatr spełniał rolę krzywego zwierciadła, które choć rozśmiesza, w tle pozostawia niepokój i lęk przed odbijanym zniekształceniem. Jak ujmowała to sentencja Stanisława Jerzego Leca, zamieszczona w programie: „Granice nieba i piekła są płynne, ale zawsze przechodzą przez nas” (Teatr Rozmaitości 1997). Teatralny lot aniołów nad ziemskim padołem w hali głównej Dworca Centralnego w Warszawie (Historia narodzenia... ) budził wątpliwości, czy świat współczesny rozpoznałby świętą rodzinę - Chrystus rodził się przecież wśród najpośledniejszych, pod koniec $\mathrm{XX}$ wieku mogłoby to wydarzyć się gdzieś między zabieganymi podróżnymi a dworcową społecznością bezdomnych.

W kolejnych realizacjach wyrastających bezpośrednio z tekstu czy kontekstu biblijnego żywioł rubasznej teatralności zaczą już jednak ustępować na rzecz surowości formy. Pretekstowo wykorzystane fragmenty Akropolis Stanisława Wyspiańskiego w połączeniu z biblijnym zapisem losów patriarchy Jakuba i słowami Księgi Koheleta w przekładzie Wujka - urosły do osobnej Historii Jakuba (Teatr Współczesny we Wrocławiu, 2001), w której zdaniem Gruszczyńskiego udało się Cieplakowi uwolnić od anegdoty i znaleźć nową formułę teatralną w zrytmizowanej recytacji (Gruszczyński 2001). W rejony minimalistycznego teatru mocno osadzonego na akcie mówienia biblijnego tekstu podążały potem kolejne wcielenia teatralne Księgi Hioba w tłumaczeniu Czesława Miłosza, którym patronowal fragment $\mathrm{z}$ wiersza poety Tak naprawdę: „Tak naprawdę nic nie rozumiem, jest tylko ekstatyczny nasz taniec, drobin wielkiej całości”. Cieplak zdawał się sprawdzać performatywność słowa, szukając w brzmieniu, melodii, rytmach, pauzach, znaczeniach ludzkiej mowy odbić Słowa-Logosu. Mówił: „nie daję wyjaśnienia, jak powinna być czytana ta księga i co z niej powinno wynikać. Proponuję sobie, aktorom i widzom zderzenie się z tą niezrozumiałością" (Cieplak 2013). Po wrocławskiej premierze Jacek Cieślak notował:

Księga Hioba w reżyserii Piotra Cieplaka to widowisko rozpisane na narratora, aktorów zasiadających za orkiestrowymi pulpitami, chór współczesnych niewiast i rockową muzykę Kormoranów. Przypomina awangardową estetykę wcześniejszych dramatów Różewicza i spektakli Grzegorzewskiego. Cieplak ograniczył do minimum działania i środki aktorskie, tak żeby spektakl przemawiał siłą ewangelicznej prostoty i tekstu przetłumaczonego przez Czesława Miłosza. Chwilami można odnieść wrażenie, że skierowany jest wyłącznie do osób wierzących, a co najwyżej wątpiących. Finałowa radość, gdy los Hioba się odwróci, przypomina klimat spotkań na pielgrzymkach i w oazach. Ktoś bardziej sceptyczny, jeśli chodzi o zbiorowe manifestacje wiary, może zobaczy w nich ocierającą się o kicz reklamę - niełatwych chrześcijańskich wyborów. A przecież Cieplak nie boi się odważnych i radykalnych środków - nabrzmiewającej bólem długiej pauzy i ostrej muzyki. Dla mnie najwspanialsze były fragmenty kobiecego chóru chwalącego cud stworzenia, życia i natury (Cieślak 2004).

Chwilami tak komponowana materia teatralna budziła opór, była męcząca, jak zauważał Patryk Kencki po Milczeniu Hioba w Teatrze Narodowym (Kencki 2013). Wybierając minimalizm, Cieplak nie rezygnował jednak z charakterystycznej dla jego przedstawień metateatralności, stawiając po raz kolejny widzów wobec metafory theatrum mundi. Echa doświadczeń nad teatralizacją tematu Hioba brzmiały potem w Nieskończonej historii Artura Pałygi 
(Teatr Powszechny, 2012), w której oratoryjna konstrukcja spotkała się z mową codzienności, polifonia dźwięków zwykłej kamienicy nakładała się na melodię ludzkich słów, a zwyczajne życie ponownie konfrontowało się z tajemnicą śmierci. Krytycy byli zgodni, że Nieskończona historia zbierała wszystko to, co stanowi o fenomenie teatru Cieplaka: perfekcyjną strukturę metateatralną rozpisaną na aktorów jako sztukmistrzów słowa oraz poezji gestu i działania w przestrzeni (ruch: Leszek Bzdyl), konstelacje dźwięków układających się w sfery, struktury niemal przestrzenne, czułą życzliwość dla zwyczajnych bohaterów i tropienie z wrażliwością Białoszewskiego metafizyki codzienności w rytuałach naszych powszechnych.

\section{Polska i Polacy}

Zaraz na początku swojej drogi reżyserskiej Cieplak odżegnywał się stanowczo od powinności narodowych, widząc, że teatr po 1989 roku ma szansę „odetchnąć od tych wszystkich przeklętych spraw" (Cieplak 1998). Ale już w 1998 roku mówił:

Teraz jednak widzę $\mathrm{w}$ tekstach romantycznych zupełnie nowe tematy i zupełnie nowe możliwości. Rzecz w tym, że jeszcze nie czuję się do tej pracy gotowy, jej skala i rozmiar przeraża mnie. Na razie o tym nie myślę (ibid.).

Cieplak wielokrotnie również zaznaczał, że nie lubi publicystyki w teatrze, ale równocześnie chciał, aby teatr tropił nerw współczesności, jej napięcia, rytmy, kryzysy. Skórą węża chorwackiego dramatopisarza Slobodana Śnajdera (Teatr Rozmaitości, 1998) zrobił pierwszy krok ku tematyce politycznych i społecznych napięć Europy końca XX wieku. Inscenizację dramatu zgwałconej kobiety z Bośni ujętego w ramy mitologicznej opowieści o zrodzeniu węża, recenzenci oceniali raczej chłodno (Majcherek 1998; Sieradzki 1998). Koszmar wojny grzązł, jak pisał Jacek Cieślak, w poetyckich, wizyjnych scenach (Cieślak 1998) i odniesieniach chrześcijańskich. Gdy po paru latach od inscenizacji bałkańskiego dramatu Cieplak zaczął dramaturgiczno-teatralną współpracę z Jerzym Pilchem (był wtedy m.in. po realizacjach dramatów Szekspira: Dwaj panowie $z$ Werony i Wesołe kumoszki $z$ Windsoru ze studentami Akademii Teatralnej, 2000, Król Lear w Teatrze Powszechnym, 2001), sprawy społeczne - obywatelskie, jak woli je nazywać Cieplak w felietonach pisanych dla portalu Teatralny.pl, i narodowe tematy zaczęły regularnie pojawiać się w twórczości reżysera, ostatnio przynosząc ponadroczne teatralne rozczytywanie romantycznego obrazu polskości z kart Pana Tadeusza Adama Mickiewicza i w narodowych mitologiach.

Nartami Ojca Świętego Piotr Cieplak wchodził po raz pierwszy na scenę Teatru Narodowego. W sztuce Pilcha odnalazł ironiczne ujęcie polskiego czekania na cud napisane w formule moralitetu, Polaków z całą pospolitością życia w małym zakątku kraju, prostą religijność ocierającą się o rutynę i wielką tęsknotę za mitem porządkującym świat, którego ucieleśnieniem był Jan Paweł II (Wyżyńska 2004). Za kluczowy moment tego spektaklu Cieplak uważał scenę,

[...] kiedy po śmieszno-strasznej nocy ujawniania kompleksów, urazów, ambicji mąż z żoną po raz pierwszy od lat rozmawiają. To jest cud oczekiwania na Ojca Świętego, który rzekomo 
miał się pojawić w Granatowych Górach. Ta perspektywa jest mi szalenie bliska. Wielkie sprawy i słowa weryfikują się w małych rzeczach. Myślę, że wszystkie moje spektakle, niezależnie od tego, jak bardzo się od siebie różnią, są opowieścią nie o herosach, ale o zwykłych ludziach, którzy mają żonę lub męża, dzieci i którzy są zagubieni, którym towarzyszy lęk, niewiedza, przerażenie bałaganem świata i którzy mimo wszystko próbują wydobyć się z chaosu. Próbują kleić z ułomków może pokraczną, ale jednak jakąś całość (Janowska 2007: 60).

Spektakl powstał na kilka miesięcy przed śmiercią papieża (granie było na jakiś czas zawieszone) i, jak się okazało, reżyser celnie zdiagnozował polską skłonność do mitologizacji oraz procesy, które po 2 kwietnia 2005 roku zamknęły Jana Pawła II w kulcie i posągach.

Szeroką gamę społecznych napięć w Polsce początku XXI wieku wydobywał Cieplak w Albośmy to jacy tacy... według Wesela Wyspiańskiego. Już w pierwszych scenach zderzył słowa z osobnych porząadków: poezji teatralnej i publicystyki. Fragment z Akropolis Wyspiańskiego brzmiał obok wyimków z gazetowych wiadomości o kolejnych politycznych sporach, które mnożą podziały na lepszych i gorszych Polaków, czy gorących akcjach społecznych, jak słynna blokada w Dolinie Rospudy. Ostre brzmienie kapeli Czerwie wyznaczało zawrotny rytm weselnej gromady i wytwarzało energię porównaną przez Artura Dudę z erupcją emocji na koncercie rockowym (Duda 2010: 104). Z rozbuchanego żywiołu tańca wyłaniały się osoby dramatu zaledwie cytujące bohaterów Wyspiańskiego. Fragmentaryczność monologów nie składała się w żadną spójną całość, była jak kalejdoskop odsłon Polaków z małych i wielkich miast, podzielonych, zwaśnionych, czepiających się złudzeń, biernych, leniwych (Miłkowski 2015). W rozmontowanym Weselu w pierwszym akcie spektaklu „wszystko się powtarza, kłębi, kotłuje. Cytuje i przedrzeźnia - pisał Łukasz Drewniak. - Na scenie nie ma chochoła jako postaci, bo u Cieplaka samo społeczeństwo jest chochołem. Wyzywa się, tańczy, międli, biega, krzyczy, bije o rząd dusz i nienawidzi do spodu" (Drewniak 2007). Jacek Kopciński notował:

Cieplak kazał zagrać aktorom samą komunikacyjną bezradność, która bardzo łatwo zamienia się w agresywną pewność ludzi, którym dialog do niczego nie jest potrzebny. W komentarzu do Albośmy to jacy, tacy... reżyser mówił o „rozjeżdżaniu” się języków w Polsce współczesnej. Miał rację. Każdy mówi tu po swojemu i do siebie, lekceważąc słuchającego, ale też nie licząc na jaką̧ś odpowiedź (Kopciński 2009).

Gdy w drugim akcie akcja przenosiła się do bronowickiej chaty, aktorzy w tradycyjnych kostiumach usadzeni $\mathrm{w}$ żywy fresk wypowiadali słowa Wyspiańskiego, jakby nieśli zaledwie pamięć brzmień, rytmu wersów, nie dialogowali nimi, mówili raczej w przestrzeń. Kopciński słusznie zwracał uwagę, że dopiero za sprawą biografii z offu, dopowiadających koleje losów prototypów postaci z Wesela, „do teatru nagle wdziera się życie, które jednak szybko gaśnie. Biograficzna opowieść brzmi tu przecież jak elegia na odejście - ale czyje? Przede wszystkim bohatera dramatycznego!” (ibid.). I konstatował:

I jeżeli mówimy dziś o narodzinach w Polsce teatru postdramatycznego, to stało się to tam, pod murkiem Powszechnego, gdzie w sytuacji quasi-spotkania, a nie regularnego spektaklu, reżyser zainscenizował kilkanaście wybuchowych monologów. Nie po to jednak, by ustanowić modny dziś wzór inscenizacyjny, raczej po to, by nas ostrzec. Jeśli chcecie być osobami dramatu, musicie nauczyć się rozmawiać - przekonywał swoim spektaklem, który był wszystkim, ale nie rozmową (ibid.). 
Nad Panem Tadeuszem Cieplak pracował z aktorami Teatru Narodowego w roku jubileuszowym polskiej sceny. Od kwietnia 2015 do marca 2016 roku powstało dwanaście czytań ksiąg epopei narodowej bez skreśleń. W trakcie kolejnych odsłon zespół odkrywał, że czytania stają się „świętem wspólnoty polszczyzny” (Cieplak 2017a), języka, który jest zakorzeniony w pamięci i który równocześnie domaga się, aby go na nowo odkrywać. Tekst Mickiewicza budził entuzjazm w toku pracy, co podzielała widownia, „ujawnił gejzer przeróżnych tonacji, poezji, piękna, ironii, złości, żartu, seksu. To jest po prostu świetny autor” - wyznawał Cieplak (Cieplak et al. 2016: 200). Po roku całość zabrzmiała podczas wielkiego maratonu teatralnego: 44 aktorów, 6 wieczorów, 14 teatralnych godzin ze słowem Mickiewicza i muzyką graną na żywo.

Inscenizowane czytanie - pisała Malwina Głowacka - przenika nostalgia za odchodzącym światem, ale także gorzka refleksja nad historią Polski, która lubi się powtarzać, i nad polską naturą, która pozostaje niezmienna mimo popełnianych w nieskończoność tych samych błędów (Głowacka 2016).

Ten gorzki ton przeniósł Cieplak do przedstawienia Soplicowo - owocilpoS. Suplement (Teatr Narodowy, 2016), w którym bez słów, za to wśród odgłosów pierwotnej komunikacji, szczekania na obcych i w rytmie utykania na kształt koślawego poloneza rozbrajał polski mit o wielkości. Cieplak wspomina:

Miałem poczucie, że po wykonaniu tej półtorarocznej pracy nad Panem Tadeuszem możemy zając się czymś innym, czyli właśnie tą Polską nieopisaną, która Pana Tadeusza nigdy nie czytała, która milczy, nie używa słów, gnuśnieje, ma nieustannie coś komuś za złe, pielęgnuje potrzebę zemsty, lęk, wzajemną agresję i nieufność (Cieplak et al. 2016: 200).

Sprowadził Polskę do rozmiarów małej, zapyziałej wsi, która przypomina rezerwat odgrodzony metalową siatką od nowoczesnego świata, jest enklawą jakiejś dziwnej tradycji podtrzymywanej przez niewyraźny już filmowy obraz Pana Tadeusza z 1928 roku, z którego została nostalgiczna scena ostatniego poloneza w Soplicowie. Wszystko, co było piękne, przeminęło, zostały tylko przeraźliwy szczek na to, co przychodzi z zewnątrz, i małe wewnętrzne zatargi. Polacy jawią się jako godna współczucia gromada obszarpańców, których jednoczy lęk przed obcymi i zatwardziałe trwanie, choćby resztkami sił, przy zniekształconej już tradycji. To bardzo ciemny obraz, Cieplak nie dał tu jasnych punktów, którymi specjalizował się w swoich egzystencjalnych, misteryjnych przedstawieniach.

\section{Teatr umuzyczniony i performatywne konstelacje twórcze}

Niezależnie od literackiego źródła, tematu, konwencji spektakle Cieplaka mają jedną wspólną cechę - są umuzycznione. Teatr Cieplaka jest świetnym przykładem zwrotu muzycznego (Burzyńska 2015) w polskim teatrze przełomu XX i XXI wieku, sygnowanego również takimi nazwiskami, jak Grzegorz Jarzyna czy Jan Klata. Przejawia się ów zwrot 
wyprowadzaniem procesu twórczego od muzyki, organizowaniem struktury teatralnej na kształt kompozycji muzycznej i nadaniem muzyce roli zasady organizującej rzeczywistość teatralną oraz odwoływaniem się do strategii percepcyjnych uruchamianych podczas koncertów (ibid.). Cieplak przyznaje: „nagrywanie dźwięków, koherentność dźwięków i muzyki towarzyszy mi od początku w pracy teatralnej. Niekoniecznie myślę o muzyce zapisywanej w nutach, ale o specyficznej aurze dźwiękowej” (Cieplak 2017b), a tę najchętniej chce słyszeć na żywo. Zespół muzyczny jest w ten sposób nierozerwalnym elementem świata przedstawionego spektakli Cieplaka, źródłem jego energii, dynamiki, również liryzmu, niezbywalną częścią gry z teatralnością światów przedstawianych na scenie. Wkomponowany w przestrzeń widowiska tworzy jeden organizm teatralny z aktorami, a to oznacza wzajemną czujność i precyzję współoddziaływania.

Audiosferę przedstawień Cieplaka naznaczały swoim stylem muzycznym zespoły rockowe, przede wszystkim Kormorany, również Czerwie (w Albośmy to jacy tacy... ), pojawiający się w obu składach Michał Litwiniec, Motion Trio (krakowscy akordeoniści nagrali muzykę do Stomkowego kapelusza), a ostatnio niezwykle intensywnie jazzowy duet SzaZa i Janusz Duszyński (Soplicowo - owocilpoS. Suplement). Maria Prussak konstatowała, że „[grana na żywo muzyka] przejmuje w tym teatrze porządkującą rolę fabuły, rytmizuje, podkreśla, puentuje, kiedy trzeba wprowadza kontrast i dysonans, zmienia kierunek akcji” (Prussak 2007: 33). Muzyka przenosiła na widowisko, jak pokazuje to Duda na przykładzie Albośmy to jacy tacy, myślenie kategoriami rockowej estetyki cytatów i sampli, powołując na scenie dzieło o unikalnej audiosferze, w której odbiorca ma się zanurzyć (Duda 2010: 105-106).

Z Kormoranami wiązały się pierwsze doświadczenia Cieplaka z kompozycjami tworzonymi na zasadzie intuicyjnej, bez nut, w duchu psychodelicznego rocka (Księżyk 2009), ambientu, jazzu nowoczesnego, z wykorzystaniem bogatego instrumentarium - rockowy zestaw wzbogacają misy, cymbały, lira korbowa czy przedmioty codziennego użytku. Jedną z ich kompozycyjnych metod jest wykorzystanie ostinata, stałego, krótkiego motywu muzycznego, który służy jako osnowa do rozmaitych wariacji ujawniających bogactwo dźwiękowych rozwinięć. W Historyi tworzyli w ten sposób rodzaj zapętleń dźwiękowych i trajektorii dla działań aktorów. Współpraca z SzaZą, jeszcze przy offowych spektaklach z Teatrem Montownia, powiodła Cieplaka w przestrzeń muzyczno-słownego performansu $O$ niewiedzy w praktyce... Muzyka jest tu partnerem, dialog dźwięków, szelestów, półtonów, improwizowanych fraz muzycznych z brzmieniami, rytmami i sensami opowieści o podróży służy zarówno kreowaniu audialnej ilustracji świata kreowanego przez Cieplaka-performera, jak i przedrzeźnianiu się z nim czy kontrapunktowaniu znaczeń ${ }^{4}$.

Jeśli można mówić o ulubionych formacjach muzycznych Cieplaka, to należy również powiedzieć o zaprzyjaźnionych niezależnych grupach teatralnych i artystach. Cieplak regularnie inwestuje swoją reżyserską energię w zdarzenia o sile, ale i nierzadko krótkotrwałości happeningu, poza scenami repertuarowymi. Gra z teatrem zdaje się dla niego wartością samą w sobie, podsyca twórczą adrenalinę. W 1999 roku zaczęła się jego współpraca z warszawskim Teatrem Montownia, sceną niezależną, która lubi teatralne szaleństwo w stylu commedii dell'arte i chętnie korzysta $\mathrm{z}$ rozmaitych technik teatru lalkowego, pantomimy i muzyki

\footnotetext{
4 Cieplak i SzaZa prezentowali ten performans w Toruniu podczas Alternatywnych Spotkań Teatralnych KLAMRA 2015 w Akademickim Centrum Kultury i Sztuki „Od Nowa”.
} 
na żywo. Z zespołem Montowni zrealizował Cieplak swoisty tryptyk: Historia o raju utraconym, czyli ... będzie lepiej (1999), Historia o narodzeniu Pana Jezusa na Dworcu Centralnym oraz Utwór sentymentalny na czterech aktorów (2008). Ostatni spektakl Dorota Jarząbek podsumowywała tak: „To nie nieufność wobec języka prowadzi Cieplaka ku pantomimie, lecz ciekawość, jak przebiega życie - poza refleksyjnym, elokwentnym, objaśniającym obszarem wysłowienia. Reżysera urzekła, by tak rzec, niewymowna codzienność” (Jarząbek 2009). Ale za najważniejszego partnera artystycznego Cieplaka należy uznać Leszka Bzdyla, tancerza, choreografa, współtwórcę teatru Dada von Bzdülöw, twórcę większości kompozycji ruchowych w przedstawieniach reżysera Historii o Miłosiernej. Wystudiowane rytmy i tempa, kompozycje przestrzenno-ruchowe, dynamika scen zbiorowych, organiczny ruch to tylko niektóre ze znaków rozpoznawczych Bzdyla, którymi podpisuje wspólne spektakle z Cieplakiem. Razem zanurzali się również w światach scenicznych bez słów, m.in. w Przed południem, przed zmierzchem (Teatr Nowy w Łodzi, 2009, we współpracy z Dada von Bzdülöw), w improwizacji (Charlie bokserem, Teatr Wybrzeże, 2010).

\section{Opowieści dla dzieci}

Trudno powiedzieć, czy do teatru dla dzieci zaprowadziła Cieplaka potrzeba „testowania teatralnych szwów", ale niewątpliwie gdy już się w nim znalazł, w jeszcze innym kontekście poddał weryfikacji swoje teatralne metody, a efekt zadziałał ożywczo na estetykę teatru dla młodszej widowni. Dobrze oceniana pierwsza realizacja dla dzieci Ach, jak cudowna jest Panama Janoscha (Teatr Lalek Banialuka im. Jerzego Zitzmana w Bielsku-Białej, 2002) otworzyła pasmo sukcesów Cieplaka w obszarze teatru dla młodego widza. W 2005 roku Cieplak wyreżyserował w warszawskim Teatrze Lalek Guliwer spektakl Amelka, Bóbr i Król na dachu Tankreda Dorsta i Ursuli Ehler, a praca nad nim przebiegała równolegle ze Stomkowym kapeluszem, stąd można było tropić wspólne elementy ich teatralnego stylu (Miernik 2005). Cieplak zdecydował się, zauważała Hanna Baltyn, na inscenizację bez inscenizacji: „Reżyser tak świetnie, z poczuciem humoru i absurdu ustawił aktorów, grających po kilka ról, że starczyli za całą dekorację" (Baltyn 2005a; Baltyn 2005b). W pustej przestrzeni, która nie kryje swojej teatralności, uruchomił żywioł gry rozpisanej na precyzyjnie skomponowane, wyraziste portrety sceniczne oryginalnych bohaterów, jak choćby dojrzała Gruszka czy pękająca Dynia, na wystudiowane gesty, rytmy wewnętrzne postaci i tonacje głosu, „co chroni je - jak w wielu inscenizacjach Cieplaka - przed ześlizgnięciem się w banał, morał, w jednoznaczność” (Prussak 2007). Spektaklem tym powrócił Cieplak do Torunia i zagrał je na scenie Teatru im. Wilama Horzycy podczas Międzynarodowego Festiwalu Teatrów Lalek „Spotkania” organizowanego przez Teatr Baj Pomorski (2005). Przedstawienie zdobyło nagrodę za inscenizację dla Piotra Cieplaka i nagrodę Jury Dziecięcego za najlepszy spektakl dla dzieci. 


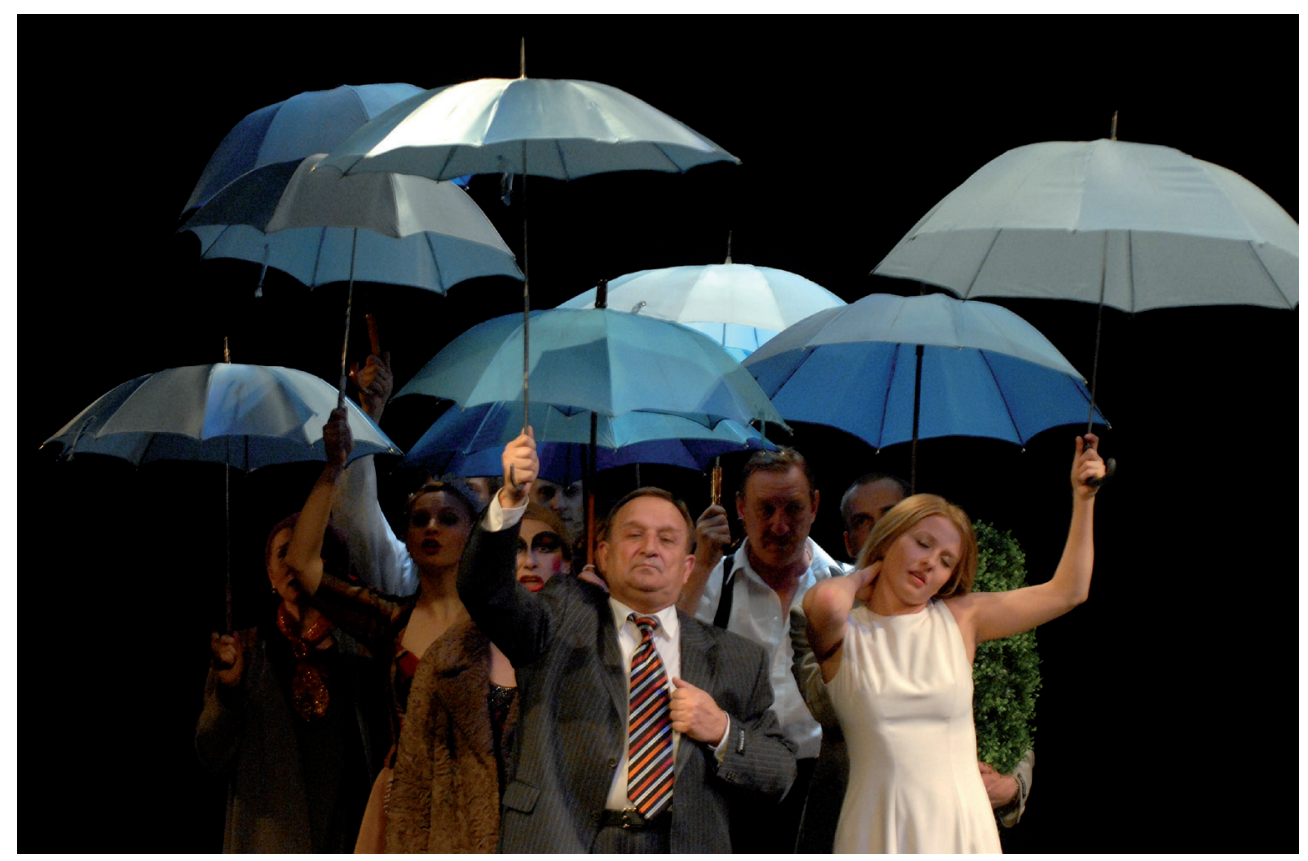

Stomkowy kapelusz Eugène Labiche’a w reż. Piotra Cieplaka (scena zbiorowa)

Fot. Wojtek Szabelski. Z archiwum Teatru im. W. Horzycy

Hanna Baltyn słusznie podkreślała, że Cieplak położył pomost między teatrem dla dzieci i teatrem dla dorosłych. Wzmocnił go kolejnymi realizacjami wystawionymi na scenie Teatru Narodowego, szczególnie Opowiadaniami dla dzieci Isaaka B. Singera (Teatr Narodowy, 2007), Królowa Śniegu (2015) i najnowszą propozycją - Elementarzem Barbary Klickiej (2017), przy czym ta jest kierowana do widza od szesnastego roku życia. W spektaklach tych stworzył Cieplak sceniczne światy zachwycające rozmachem inscenizacyjnym i widowiskową multimedialnością, które śmiało można określić „apologią teatru, zabawą z teatralnością, siłą konwencji i zarazem miejscem ukazywania, bez uproszeń i banalności, piękna człowieka w jego najprostszych gestach, a nade wszystko w jego byciu dla drugiego człowieka" (Wakar 2015). Podobnie jak swego czasu Historia o miłosiernej, dwa pierwsze $\mathrm{z}$ wymienionych tytułów zyskały rangę kultowych i prawdopodobnie wielu niedawnych widzów w martensach $\mathrm{z}$ Rozmaitości odnalazło w nich razem ze swoimi dziećmi teatr, w którym cały czas teatralność paradoksalnie doprowadza do tego, co prawdziwe, co najważniejsze i najbardziej podstawowe. W Elementarzu, scenicznej egzegezie słów i języka, przeznaczonej dla niemal dorosłego widza, Cieplak kontynuuje gry z teatralnością - scena jest tu w ciągłej metamorfozie, notował w recenzji Piotr Olkusz, a powołana „maszyneria do gry” pełna jest „składników, które można ze sobą łączyć jak alfabet, odmieniać przez przypadki jak słowa" (Olkusz 2018).

O osobności teatru Cieplaka mówi się zazwyczaj w kontekście misteryjno-moralitetowego i eschatologicznego paradygmatu jego przedstawień. Tymczasem nie mniej wyrazistą cechą, a na pewno określającą tak naprawdę wiele nurtów twórczości Cieplaka, jest dociekliwe testowanie teatralności teatru. Sprawdza on teatr jako scenę świata, na której 
obowiązują prawa udawania, gry, iluzji, ramy różnych konwencji, ale równocześnie jest ona miejscem żywej współ-obecności wykonawców/performerów i widzów/uczestników, ich energetycznej wymiany. Demonstrując machinę teatru i zarazem rozsadzając ją m.in. dzięki zastosowaniu estetyki teatru alternatywnego, zasady dekonstrukcji i muzyczności o rockowych źródłach, Cieplak stworzył autorską formułę teatru, w którym pielęgnowanie rozmowy o wartościach podstawowych, zobowiązaniach człowieka wobec siebie i drugiego, o rudymentach życia w społeczności, idzie w parze z poszukiwaniem kształtu, rytmu, brzmienia przedstawienia odpowiadającego na wyzwania przemian kulturowych przełomu wieków.

\section{Bibliografia}

Baltyn, Hanna 2005a. „Amelka”. Teatr Lalek 2-3 (81-82).

— 2005b. „Dobrze przemyślane”. Foyer 13-14 (07-08).

Burzyńska, Anna R. 2015. „Polski teatr współczesny z ducha muzyki”. Teatr 11.

Cieplak, Piotr 1997. „Nie ma średniego pokolenia. Rozmawiał J. Cieślak”. Rzeczpospolita 87.

— 1998. „Niektórzy przez teatr. Z Piotrem Cieplakiem rozmawia Piotr Gruszczyński”. Tygodnik Powszechny 34 (23.08).

- 2002. „Zawsze dużo. Z Piotrem Cieplakiem rozmawiali Agnieszka Celeda i Jacek Sieradzki”. Polityka 5 (02.02).

— 2007. „Nie jestem Miłoszem teatru. Z Piotrem Cieplakiem rozmawia Paweł Sztarbowski”. Opcje 1: 59-63.

— 2013. „Zderzenie z niezrozumiałością. Rozmawia E. Uniejewska”. http://teatralny.pl/rozmowy/ zderzenie-z-niezrozumialoscia,77.html [17.07.2017].

-2014. O niewiedzy w praktyce. Droga do Portugalii. Wrocław: Fundacja Teatr Nie-Taki.

- (et al.) 2016. „Powinność wieszcza. Dyskutują Piotr Cieplak, Tadeusz Słobodzianek oraz Sebastian Duda”. Więź 3 (07/09): 200.

- 2017a. „Kwitnący ogródek Zosi. Rozmowa z Piotrem Cieplakiem”. http://www.narodowy. pl/aktualności,333,kwitnacy_ogrodek_zosi_rozmowa_z_piotrem_cieplakiem.html [17.07.2017].

— 2017b. „O królestwie, przynoszeniu kwiatów i przyjaźni, czyli podróż Cieplaka w dźwięk”. http:// www.polskieradio.pl/17/1137/Artykul/741734,O-krolestwie-przynoszeniu-kwiatow-i-przyjazni-czyli-Piotra-Cieplaka-podroz-w-dzwiek [14.07.2017].

Cieślak, Jacek 1998. „Piekło nie przedstawione”. Rzeczpospolita 122 (26.05).

— 2004. „Hiobowe wieści dla scenicznych monopoli”. Rzeczpospolita 288 (09.12).

Drewniak, Łukasz 2007. „Nieproszeni weselnicy”. Dziennik 221 (21.09).

Duda, Artur 2010. „Na śmietniku popkultury. Teatr polski po 1989 r. z perspektywy estetyki performatywności”. W: Dorota Jarząbek, Marcin Kościelniak, Grzegorz Niziołek (red.). 20-lecie. Teatr polski po 1989. Kraków 2010: Korporacja HA!ART.

Głowacka, Malwina 2016. „Święta księga”. http://teatralny.pl/recenzje/slowo-wprawione-wruch,1609.html [17.07.2017].

Goźliński, Paweł 1998. „Teatr Cieplaka”. Notatnik Teatralny 16-17: 65-77.

Gruszczyński, Piotr 1997. „Pieski testament”. Tygodnik Powszechny (12.10).

— 2001. „Przesłanie Pana C... Tygodnik Powszechny 5 (04.02).

- 2003. Ojcobójcy. Młodsi zdolniejsi w teatrze polskim. Warszawa: Wydawnictwo W.A.B.

Jagła, Marek 1991. „Ameryka na scenie”. Ilustrowany Kurier Polski 246 (20-22.12).

Janikowski, Grzegorz 1998. „Zaklinacz widzów”. Twój Styl 3: 120. 
Janowska, Katarzyna 2007. „Mnóstwo rzeczy mnie wkurza. Rozmowa z Piotrem Cieplakiem”. Polityka 35 (01.09): 58-60.

Jarząbek, Dorota 2009. „Teatr bez słów”. Didaskalia 6.

Jarmuż, Sylwia 2013. „Teatr staropolski w teatrze Piotra Cieplaka”. Pamiętnik Teatralny 2 (246): $100-116$.

— 2014. „Donosy rzeczywistości' i 'obroty rzeczy’ - o miłości, odpowiedzialności i dzielności w teatrze Piotra Cieplaka”. Kultura Wspótczesna 1: 113-133.

Kopciński Jacek 2009. „Wolni dwudziestoletni. Ankieta”. Teatr 9.

Kencki, Patryk 2013. „Szkice o Hiobie”. http://teatralny.pl/recenzje/szkice-o-hiobie,86.html [15.07.2017].

Kozłowska, Justyna 2005. „Kohelet z wodewilu”. Dialog 6: 148-153.

- 2008a. „Teatr Piotra Cieplaka: Od Fredry do Becketta”. Pamiętnik Teatralny 1-2: 240-268.

- 2008b. „Zamiast mroków widzę jasność”. Dialog 9.

Kornaś, Tadeusz 2010. „Eschatologie Piotra Cieplaka”. W: Dorota Jarząbek, Marcin Kościelniak, Grzegorz Niziołek (red.). 20-lecie. Teatr polski po 1989. Kraków 2010: Korporacja HA!ART.

Księżyk, Rafał 2009. „Jesteśmy poszukiwaczami”. Dziennik online - dodatek Kultura 19 (23.01). http://www.e-teatr.pl/pl/artykuly/65706,druk.html [15.07.2017].

Majcherek, Janusz 1993. „Chwalebne Zmartwychwstanie “Historyi ...”. Teatr 12.

— 1998. „Wojna i wąż”. Express Wieczorny 115 (18.05).

Miernik, Bartłomiej 2005. „Amelka i Dina”. Teatr 9.

Miłkowski, Tomasz 2015. „Duch się w każdym poniewiera”. Przegląd 5 (28.01).

Olkusz, Piotr 2018. „Las znaczeń”. http://teatralny.pl/recenzje/las-znaczen,2223.html [12.04.2018].

Pawłowski, Roman 1997. „Nieawangardowy off. Rozmowa z Piotrem Cieplakiem, dyrektorem artystycznym warszawskiego Teatru Rozmaitości". Gazeta Wyborcza 160 (11.07).

Prussak, Maria 2003. „Zadawanie pytań. Z Piotrem Cieplakiem rozmawia Maria Prussak”. Didaskalia 58.

- 2007. „Teatr jest od tropienia rzeczy niewidzialnych. Piotr Cieplak”. Kronika Warszawy 4/135: 27-36.

Sieradzki, Jacek 1998. „Bałkańskie kłębowisko”. Polityka” 25 (20.06).

Teatr Rozmaitości 1997. „Program do przedstawienia “Historia o Miłosiernej, czyli Testament psa”. http://www.e-teatr.pl/pl/programy/2013_12/57734/testament_psa_teatr_rozmaitosci_warszawa_1997.pdf [17.07.2017].

Teatr Współczesny im. Edmunda Wiercińskiego we Wrocławiu 1993/1994. „Program przedstawienia 'Historyja o chwalebnym Zmartwychwstaniu Pańskim”'. http://www.e-teatr.pl/pl/ programy/2013_12/56941/historyja_o_chwalebnym wroclawski teatr_wspolczesny_1993.pdf [10.07.2017].

Tischner, Józef 1998. Filozofia dramatu. Kraków: Wydawnictwo Znak.

Wakar, Jacek 2015. „Królowa śniegu’ Cieplaka bawi się teatrem”. Gazeta Prawna. http://www.gazetaprawna.pl/artykuly/849239,wakar-krolowa-sniegu-cieplaka-bawi-sie-teatrem.html [15.07.2017].

Wyżyńska, Dorota 2004. „Bardzo malutki moralitet”. Gazeta Wyborcza Stoteczna 261 (06.11). 